\title{
ANALISA YURIDIS TENTANG STATUS KEWARGANEGARAAN ANAK HASIL PERKAWINAN CAMPURAN MENURUT UNDANG-UNDANG NOMOR 12 TAHUN 2006 TENTANG KEWARGANEGARAAN INDONESIA
}

\author{
Evi Purnama Wati, \\ Fakultas Hukum Universitas Palembang \\ Email:evipurnamawatiplg@gmail.com
}

\begin{abstract}
The citizenship status of a child born of a mixed marriage under Law No. 12 of 2006 on Indonesian Citizenship is a positive enlightenment, since the Act allows for limited dual citizenship for a child of mixed marriage, up to the age of 18 years, the child is entitled to choose citizenship which he wanted and given time to think for 3 years. Whereas in Law Number 62 Year 1958 on Citizenship, the Status of the nationality of a child follows the citizenship of his father. Limitation on the rights and obligations of a child born of a mixed marriage under Law Number 12 of 2006 on Indonesian Citizenship is to have the same rights and obligations that a person of a citizen with a dual citizenship status is legally recognized as being citizen in both countries: Indonesian Citizen and Foreigners. Since he is a resident of both countries, the inherent rights due to his citizenship must also be fully provided by the state and the state shall not limit his rights as a citizen of both countries.
\end{abstract}

Keywords: Nationality; Mixed Marriage; Child.

\begin{abstract}
ABSTRAK
Status kewarganegaraan anak yang lahir dari perkawinan campuran menurut Undang Undang Nomor 12 Tahun 2006 Tentang Kewarganegaraan Indonesia adalah memberikan pencerahan yang positif, karena Undang - Undang ini mengizinkan kewarganegaraan ganda terbatas untuk anak hasil perkawinan campuran, sampai batas umur 18 Tahun, maka anak berhak memilih kewarganegaraan yang diinginkannya dan diberikan waktu untuk berpikir selama 3 tahun. Sedangkan di dalam Undang-Undang Nomor 62 Tahun 1958 tentang Kewarganegaraan, Status kewarganegaraan anak mengikuti kewarganegaraan ayahnya. Batasan hak dan kewajiban anak yang lahir dari perkawinan campuran menurut Undang-Undang Nomor 12 Tahun 2006 tentang Kewarganegaraan Indonesia adalah Mempunyai hak dan kewajiban yang sama yaitu Seseorang warga negara berstatus kewarganegaraan ganda terbatas secara hukum diakui kebaradaannya sebagai warga negara di kedua negara yaitu Warga Negara Indonesia dan Warga Negara Asing. Oleh karena ia adalah warga di kedua negara, maka hak-hak yang melekat karena status kewarganegaraannya harus juga diberikan secara utuh oleh negara dan negara tidak boleh membatasi hak-haknya sebagai warga negara dari kedua negara.
\end{abstract}

Kata Kunci: Kewarganegaraan; Perkawinan Campuran; Anak

\section{PENDAHULUAN}

\section{A. Latar Belakang}

Perkawinan campuran telah merambah seluruh pelosok tanah air dan kelas masyarakat. Globalisasi Informasi, ekonomi, pendidikan dan transportasi telah menggugurkan stigma bahwa kawin campur adalah perwakinan antara expatariat kaya dengan orang Indonesia.

Menurut survey yang dilakukan oleh Mixed Couple Club, jalur perkenalan yang membawa pasangan yang berbeda kewarganegaraan menikah antara lain adalah perkenalan melalui Internet, kemudian bekas 
teman kerja/bisnis, berkenalan saat berlibur, bekas teman sekolah/kuliah dan sahabat pena. Perkawinan campur juga terjadi pada Tenaga Kerja Indonesia dengan Tenaga Kerja dari Negara Asing. Salah satu contoh:Titi Dj dan Hendrawan, atlet bulu tangkis yang menjadi kebanggaan bangsa Indonesia, mungkin sebagian kecil dari ratusan contoh bahkan ribuan kasus diskriminasi terhadap "warga negara" yang dianggap asing atau "anak tiri" oleh negaranya untuk memperoleh status hukum anak. Dengan terjadinya banyak perkawinan campur ini di Indonesia yang berdasarkan dengan hukum (rechtstaat) sudah seharusnya perlindungan hukum dalam perkawinan campur ini diakomodir dengan baik dalam perundang-undangan di Indonesia.

Dewasa ini sedang semaraknya pernikahan beda Negara dikalangan selebritis terutama di Indonesia.Perkawinan beda Negara bukan hal yang mudah untuk dilaksanakan tetapi bukan juga hal yang susah untuk dilaksanakan oleh pasangan yang memilih menikah dengan warga Negara asing atau WNA sebenarnya bukan hanya dikalangan selebritis saja yang maraknya menikah beda Negara mungkin karena mereka banyak disorot oleh masyarakat jadi apa yang mereka lakukan menjadi konsumsi publik, tetapi rakyat biasa pun tidak lepas menikah dari yang namanya menikah beda Negara.

Dalam perundang-undangan di Indonesia, perkawinan campuran didefenisikan dalam Undang-undang Nomor. 1 Tahun 1974 tentang perkawinan, pasal 57:

"Yang dimaksud dengan perkawinan campuran dalam Undang-undang ini ialah perkawinun antura dua orang yang di Indonesia tunduk pada hukum yang berlainan, karena perbedaaan kewarganegaraan Indonesia."

Sebelum Undang-undang perkawinan tersebut keluar, di Indonesia berlaku ketentuanketentuan yang diatur dalam Kitab UndangUndang Hukum Sipil Ordonasi Perkawinan Indonesia, Kristen, Jawa, Minahasa, dan Ambon (Huwelijke ordinantie voor Christen Indonesiece Java Minahasaen, Amboina) staatblad 1933 Nomor 74 jo 36-607 jo L.N 1846 No. 136 ini disingkat H.O.C.L Peraturan Perkawinan Campuran, staatblad 1898 Nomor 158 dan undang-undang Percatatan nikah, talak, dan rujuk, lembaran Negara 1954 Nomor 32 serta Peraturan-peraturan menteri agama mengenai pelaksanaannya.Selama hampir setengah abad pengaturan kewarganegaraan dalam perkawinan campuran antara warga Negara Indonesia dengan warga Negara asing, mengacu pada Undang-undang kewarganegaraan Nomor. 62 Tahun 1958. Seiring berjalannya waktu Undang-undang ini dinilai tidak sanggup lagi mengakomodirkepentingan para pihak dalam perkawinan campuran, terutama untuk perlindungan istri dan anak.

Barulah pada 11 Juli 2006, DPR mengesahkan undang-undang Kewarganegaraan yang baru yaitu Undangundang Nomor 12 Tahun 2006 dengan lahirnya undang-undang ini disambut gembira oleh sekelompok kaum ibu yang menikah dengan warga Negara asing, walaupun pro dan kontra masih saja timbul, namun secara garis besar Undang-undang tersebut yang memperbolehkan dwi kewarganegaraan ini sudah memberikan pencerahan dalam mengatasi persoalan-persoalan yang lahir dari perkawinan campuran.

Persoalan yang rentan dan sering timbul dalam perkawinan campuran adalah masalah kewarganegaraan anak. Undangundangtentang kewarganegaraan yang lama menganut prinsip kewarganegaraan tunggal, sehingga anak yang lahir dari perkawinan campuran hanya memiliki satu kewarganegaraan, yang dalam Undangundang tersebut ditentukan bahwa yang harus diikuti adalah kewarganegaraan ayahnya. Pengaturan ini menimbulkan persoalan apabila di kemudian hari perkawinan orang tua pecah, tentu ibu kesulitan mendapat pengasuhan anaknya yang warga Negara asing.

Dengan lahirnya Undang-undang Kewarganegaraan tersebut, sangat menarik untuk dikaji bagaimana pengaruh lahirnya undang-undang tersebut terhadap status 
kewarganegaraan anak dari perkawinan campuran. Oleh karena itu, apabila hukum di Indonesia dan terutama Islam mengatur masalah perkawinan dengan amat teliti dan terperinci, untuk mendapatkan garis keturunan dan membawa umat manusia khususnya anak berkehormatan, sesuai kedudukannya yang amat mulia ditengahtengah mahluk Tuhan.

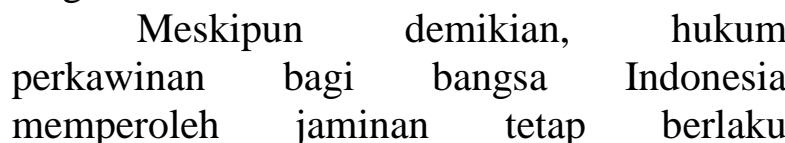
sebagaimana dapat dipahami dengan jelas dari undang-undang Nomor. 1 Tahun 1974 tentang Perkawinan di dalam pasal 2 ayat 1 menyatakan : perkawinan adalah sah apabila dilakukan menurut hukum masing-masing agama dan kepercayaan itu. Hal ini sejalan pula dengan jaminan pada pasal 29 UUD 1945 yang bersumber kepada sila ketuhanan Yang Maha Esa pada dasar falsafah Negara Pancasila.

Mengingat peranan hidup bersama sangat penting bagi tegak dan sejahteranya masyarakat, maka Negara membutuhkan tata tertib dan kaidah-kaidah yang mengatur hidup bersama ini dan peraturan-peraturan inilah yang menimbulkan pengertian perkawinan, yaitu hidup bersama dari seorang laki-laki dan seorang perempuan yang memenuhi syaratsyarat yang termasuk dalam peraturan tersebut.

Ada beberapa pasangan baik itu perempuan atau laki-laki yang menikah dengan Warga Negara Asing, terutama untuk wanita biasanya jika seseorang wanita menikah dengan Warga Negara Asing, kita ambil contoh wanita Warga Negara Indonesia berada di Negara Amerika dan melangsungkan perkawinan dengan laki-laki Warga Negara Amerika maka sah perkawinan tersebut karena berdasarkan Undang-Undang Nomor 1 Tahun 1974 tentang Perkawinan di dalam pasal 56 ayat 1 yang menyatakan: Perkawinan di Indonesia antara dua orang warga negara Indonesia atau seorang warga negara Indonesia dengan warga negara Asing adalah sah bilamana dilakukan menurut hukum yang berlaku di Negara dimana perkawinan itu di langsungkan dan bagi warga Negara Indonesia tidak melanggar ketentuan Undang- undang ini.

Anak-anak yang lahir dari hasil perkawinan campuran adalah kelompok yang rentan, di mana diperlukan perlakuan khusus akibat keadaannya itu. Berbagai perlindungan yang seyogianya diberikan kepada anak warga Negara Indonesia telah dicoba dirancang seperti dalam Undang-Undang Nomor 23 Tahun 2002 tentang Perlindungan Anak.

Undang-Undang Nomor 23 Tahun 2002 tentang Perlindungan Anak di dalam Pasal 29 Ayat 3 dalam hal putusnya perkawinan akibat perceraian, diatur adanya kemungkinan bagi Negara melalui pengadilan negeri atas permohonan ibu warga Negara Indonesia untuk mengganti kewarganegaraan asing anak menjadi warga kewarganegaraan anak dalam pengaturan status kewarganegaraan anak hasil perkawinan campuran di dalam undang-undang kewarganegaraan yang baru yaitu UndangUndang Nomor 12 Tahun 2006 tentang Kewarganegaraan Indonesia.

Adapun asas-asas yang terkandung didalam Undang - Undang Nomor 12 Tahun 2006 tentang kewarganegaraan Indonesia adalah :

1. Asasius sanguinis (law of the blood) adalah asas yang menentukan kewarganegaraan seseorang berdasarkan keturunan bukan berdasarkan negara tempat kelahiran;

2. Asas ius soli (law of the soil) secara terbatas adalah asas yang menentukan kewarganegaraan seseorang berdasarkan Negara tempat kelahiran, yang diberlakukan terbatas bagi anak-anak sesuai dengan ketentuan yang diatur dalam Undang-Undang ini;

3. Asas kewarganegaraan tunggal adalah asas vang menentukan satu kewarganegaraan bagi setiap orang;

4. Asas kewarganegaraan ganda terbatas adalah asas yang menentukan kewarganegaraan ganda bagi anak-anak 
sesuai ketentuan yang diatur dalam undang-undang ini. ${ }^{1}$

Undang-Undang ini pada dasarnya tidak mengenal kewarganegaraan ganda (bipatride) ataupun (apatride). Kewarganegaraan ganda yang diberikan kepada anak dalam Undang-Undang ini merupakan suatu pengecualian.

Adapun beberapa undang-undang yang berlaku dan pernah berlaku di Indonesia tentang kewarganegaraan sejak Proklamasi Kemerdekaan Republik Indonesia sampai sekarang :

1. Undang-Undang Nomor 3 Tahun 1946 tentang Warga Negara dan Penduduk Negara;

2. Undang-Undang Nomor 6 Tahun 1974 tentang Perubahan Undang-Undang Nomor 3 Tahun 1946;

3. Undang-Undang Nomor 8 Tahun 1947 tentang Perpanjangan Waktu Untuk Mengajukan Pernyataan Berhubung Dengan KewarganegaraanIndonesia;

4. Undang-Undang Nomor 11 Tahun 1948 tentang Perpanjangan Waktu Lagi Untuk Mengajukan Pernyataan Berhubung Dengan KewarganegaraanIndonesia;

5. Undang-Undang Nomor 62 Tahun 1958 tentang Kewarganegaraan Republik Indonesia;

6. Undang-Undang Nomor 3 Tahun 1976 tcntang Perubahan Pasal 18 UndangUndang Nomor 62 Tahun 1958 tentang Kewarganegaraan Republik Indonesia;

7. Undang-Undang Nomor 12 Tahun 2006 tentang Kewarganegaraan Indonesia. ${ }^{2}$

\section{B.Permasalahan}

Dari latar belakang tersebut di atas, maka dapat dirumuskan dua permasalahan dalam penelitian ini, yaitu :

1. Bagaimana status kewarganegaraan anak yang lahir dari perkawinan campuran menurut Undang-undang Nomor 12

1 Hadi Setia Tunggal., Tanya Jawab Kewarganegaraan Baru Berdasarkan Undang-Undang No. 12 Tahun 2006, Harvarindo, 2006, hlm.11.

${ }^{2}$ Ibid, hlm. 4.
Tahun 2006 tentang Kewarganegaraan Indonesia?

2. Bagaimanakah batasan-batasan hak dan kewajiban anak hasil perkawinan campuran menurut Undang-undang Nomor 12 Tahun 2006 tentang Kewarganegaraan Indonesia?

\section{Tujuan Penelitian}

1. Untuk mengetahui status kewarganegaraan anak hasil perkawinan campuran sebelum dan sesudah lahirnya Undang-Undang Nomor 12 Tahun 2006.

2. Untuk mengetahui pengaturan dan batasan-batasan hak dan kewajiban yang diberikan oleh Negara terhadap anak tersebut.

\section{Metode Penelitian}

Metode penelitian yang penulis gunakan dalam penelitian ini adalah Normatif;

1. Sumber Data

Penelitian ini hanya menggunakan data sekunder baik yang berupa bahan-bahan primer, seperti Undang-Undang, peraturanperaturan yang ada kaitan dengan yang lainnya, dan bahan hukum sekunder, seperti karya ilmiah, buku, majalah atau surat kabar dan lain-lain yang relevan dengan penelitian ini;

2. Teknik Pengumpulan Data

a. Study pustaka (library research), yaitu teknik pengumpulan data yang dilakukan dengan cara menelusuri literatur-literatur, dokumen-dokumen, dan peraturan perundang-undangan yang terkait dengan penelitian ini.

b. Penelitian lapangan (field research), yaitu penelitian langsung dengan interview (wawancara) kepada pada pihak Pengadilan Negeri Palembang dan Kantor Dinas Kependudukan Catatan Sipil Palembang (responden), hal ini diharapkan 
akan diperoleh data yang memadai dari masalah-masalah yang diteliti, untuk mencapai dan mengumpulkan data yang dibutuhkan yang berguna dalam penyusunan penelitian ini.

\section{Metode Pendekatan}

Metode pendekatan yang digunakan dalam penelitian ini adalah :

Metode pendekatan sosiologis/empiris yaitu meninjau dan membahas objek penelitian dengan penekanan pada landasan historis pada objek penelitian dengan tidak bermaksud menguji hipotesis.

4. Teknik pengolahan data dilakukan dengan menerapkan analisis isi terhadap data tekstular dan kualitatif terhadap data lapangan yang selanjutnya dirumuskan dalam kesimpulan.

\section{PEMBAHASAN}

A. Status Kewarganegaraan Anak Hasil Perkawinan Campuran Menurut Undang-undang No 12 Tahun 2006

I. Menurut Undang-Undang Kewarganegaraan Nomor62 Tahun 1958

a. Landasan UUD Sementara 1950 dan mengacu Staat - Blaad 1910 - 296;

b. Asasius sangunis;

c. Mengakui kewarganegaraan ganda terbatas pada anak - anak pada usia 18 tahun;

d. Mensyaratkan SBKRI untuk WNI keturunan;

e. Perkawinan Ibu WNI menikah dengan Pria WNA otomatis jadi WNA;

f. Anak hasil perkawinan ibu WNI dengan pria WNA adalah otomatis WNA;

1. Permasalahan Dalam Perkawinan Campuran

a. Pria Warga Negara Asing (WNA) menikah dengan Wanita Warga Negara Indonesia (WNI).Berdasarkan pasal 8 Undang-Undang Nomor 62 Tahun 1958, seorang perempuan warga negara Indonesia yang menikah dengan seorang warga Negara asing bisa kehilangan kewarganegaraannya, apabila selama waktu satu tahun ia menyatakan keterangan untuk itu, kecuali apabila dengan kehilangan kewarganegaraan tersebut.

b menjadi tanpa kewarganegaraan. Apabila suami WNA bila ingin memperoleh kewarganegaraan Indonesia maka harus memenuhi persyaratan yang ditentukan bagi WNA biasa. Karena sulitnya mendapat izin tinggal di Indonesia bagi laki-laki WNA sementara istri WNI tidak bisa meninggalkan Indonesia karena satu dan lain hal (faktor bahasa, budaya. keluarga besar, pekerjaan pendidikan,dll) maka banyak pasangan hidup dalam keterpisahan;

b. Wanita Warga Negara Asing (WNA) yang menikah dengan Pria Warga Negara Indonesia (WNI).Indonesia menganut asas kewarganegaraan tunggal sehingga berdasarkan pasal 7 Undang-undang Nomor 62 Tahun 1958 apabila seorang perempuan WNA menikah dengan pria WNI, ia dapat memperoleh kewarganegaraan Indonesia tapi pada saat yang sama ia juga harus kehilangan kewarganegaraan asalnya. Permohonan untuk menjadi WNI pun harus dilakukan maksimal dalam waktu satu tahun setelah pernikahan, bila masa itu terlewati, maka pemohonan untuk menjadi WNI harus mengikuti persyaratan yang berlaku bagi WNA biasa. Untuk dapat tinggal di Indonesia perempuan WNA ini mendapat sponsor suami dan dapat. memperoleh izin tinggal yang harus diperpanjang setiap tahun dan memerlukan biaya serta waktu untuk pengurusannya. Bila suami meninggal, maka ia akan kehilangan sponsor dan otomatis keberadaannya di Indonesia menjadi tidak jelas Setiap kali melakukan perjalanan keluar negeri memerlukan rentry permit yang permohonannya harus disetujui suami sebagai sponsor. Bila suami meninggal 
tanah hak milik yang diwariskan suami harus segera dialihkan dalam waktu satu tahun. Seorang wanita WNA tidak dapat bekerja kecuali dengan sponsor perusahaan. Bila dengan sponsor suami hanya dapat bekerja sebagai tenaga sukarela. Artinya sebagai istri/ibu dari WNI, perempuan ini kehilangan hak berkontribusi pada pendapatan rumah tangga.

\section{Anak hasil Perkawinan Campuran}

Indonesia

kewarganegaraan menganut tunggal,

asas kewarganegaraan anak mengikuti ayah, sesuai pasal 13 ayat (1) Undang-Undang Nomor. 62 Tahun 1958 :

"Anak yang belum berumur 18 tahun dan belum kawin yang mempunyai hubungan hukum kekeluargaan dengan ayahnya sebelum ayah itu memperoleh kewarganegaraan Republik Indonesia, turut memperoleh kewarganegaraan Republik Indonesia setelah ia bertempat tinggal dan berada di Indonesia. Keterangan tentang bertempat tinggal dan berada di Indonesia itu tidak berlaku terhadap anak-anak yang karena ayahnya memperoleh kewarga-negaraan Republik Indonesia menjadi tanpa kewarganegaraan."

Dalam ketentuan Undang-undang kewarganegaraan ini, anak yang lahir dari perkawinan campuran bisa menjadi warganegara Indonesia dan bisa menjadi warganegara asing :

\section{a. Menjadi Warganegara Indonesia}

Apabila anak tersebut lahir dari perkawinan antara seorang wanita warga negara asing dengan pria warga negara Indonesia (pasal 1 huruf $\mathrm{b}$ Undang-undang Nomor 62 Tahun 1958), maka kewarganegaraan anak mengikuti ayahnya, kalaupun Ibu dapat memberikan kewarganegaraannya, si anak terpaksa harus kehilangan kewarganegaraan lndonesianya. Bila suami meninggal dunia dan anak masih dibawah umur, tidak jelas, apakah istri bisa menjadi wali bagi anak-anaknya yang menjadi WNI di Indonesia. Bila suami (yang herstatus pegawai negeri) meningggal tidak jelas apakah istri (WNA) dapat memperoleh pensiun suami karena birokrasi proses pengalihan gaji pensiun.

b. Menjadi Warga Negara Asing

Apabila anak tersebut lahir dari perkawinan antara seorang wanita warganegara Indonesia dengan warganegara asing. Anak tersebut sejak lahirnya dianggap sebagai warga negara asing sehingga harus dibuatkan Paspor di Kedutaan Besar Ayahnya, dan dibuatkan kartu izin Tinggal Sementara (KITAS) yang harus terus diperpanjang dan biaya pengurusannya tidak murah. Dalam hal terjadi perceraian, akan sulit bagi ibu untuk mengasuh anaknya, walaupun pada pasal 3 Undang-undang Nomor 62 Tahun 1958 dimungkinkan bagi seorang ibu WNI yang bercerai untuk memohon kewarganegaraan Indonesia bagi anaknya yang masih di bawah umur dan berada dibawah pengasuhannya, namun dalam praktek hal ini sulit dilakukan. Masih terkait dengan kewarganegaraan anak, dalam Undang-undang Nomor 62 Tahun 1958, hilangnya kewarganegaraan ayah juga mengakibatkan hilangnya kewarganegaraan anakanaknya yang memiliki hubungan hukum dengannya dan belum dewasa (belum berusia 18 tahun atau belum menikah). Hilangnya kewarganegaraan ibu, juga mengakibatkan kewarganegaraan anak yang belum dewasa (belum berusia 18 tahun/ belum menikah) menjadi hilang (apabila anak tersebut tidak memiliki hubungan hukum dengan ayahnya).

\section{Menurut Undang-Undang Nomor 12 Tahun 2006}

a. Landasan Perubahan UUD 1945;

b. Asas campuran ius soli dan ius sangunis;

c. SBKRI (Surat Bukti Kewarganegaraan Republik Indonesia) tidak diperlukan;

d. Perempuan Warga Negara Indonesia (WNI) menikah dengan pria Warga Negara Asing (WNA) tidak otomatis jadi WNA;

e. Anak Perkawinan ibu WNI dengan Pria WNA adalah WNI sampai usia 18 tahun. 


\section{Pengaturan Mengenai Anak Hasil Perkawinan Campuran. \\ Undang-Undang Kewarganegaraan} Indonesia Nomor 12 Tahun 2006 memuat asas-asas kewarganegaraan umum atau universal, yaitu :

1. Asasius sanguinis (law of the blood).

2. Asas ius soli (law, of the soil) secara terbatas.

3. Asas kewarganegaraan tunggal.

4. Asas kewarganegaraan ganda terbatas.

Undang-Undang ini pada dasamya tidak mengenal kewarganegaraan ganda (bipatride) ataupun tanpa kewarganegaraan ( $a$ patride). Kewarganegaraan ganda yang diberikan kepada anak dalam Undang-Undang ini merupakan suatu pengecualian.Mengenai hilangnya kewarganegaraan anak, maka hilangnya kewarganegaraan ayah atau ibu (apabila anak tersebut tidak punya hubungan hukum dengan ayahnya) tidak secara otomatis menyebahkan kewarganegaraan anak menjadi hilang.

Selain asas tersebut diatas, beberapa asas khusus juga yang menjadi dasar penyusunan Undang-Undang tentang Kewarganegaraan Republik Indonesia, yaitu :

a. Asas kepentingan nasional adalah yang mencantumkan bahwa peraturan kewarganegaraan mengutamakan kepentingan nasional Indonesia, yang bertekad mempertahankan kedaulatannya sehagai negara kesatuan yang memiliki cita-cita dan tujuannya sendiri;

b. Asas perlindungan maksimum adalah asas yang menentukan bahwa pemerintah wajib memberikan perlindungan penuh kepada setiap Warga Negara Indonesia dalam keadaan apapun baik di dalam maupun di luar negeri;

c. Asas persamaan di dalam hukum dan pemerintahan adalah asas yang menentukan bahwa setiap Warga Negara Indonesia mendapatkan perlakuan yang sama dalam hukum dan pemerintahan; d. Asas kebenaran substantif adalah prosedur pewarganegaraan seseorang tidak hanya bersifat administratif, tetapi juga disertai substansi dan syarat-syarat permohonan yang dapat dipertanggung jawabkan kebenarannya;

e. Asas non diskriminatif adalah asas yang tidak membeda-bedakan perlakuan dalam segala hal ikhwal yang berhuhungan dengan warga negara atas dasar suku, ras, agama, golongan, jenis kelamin dan gender;

f. Asas pengakuan dan penghormatan terhadap hak asasi manusia adalah asas yang dalam segala ikhwal yang berhubungan dengan warga negara harus menjamin, melindungi, dan memuliakan hak asasi manusia pada umumnya dan hak warga negara pada khususnya;

g. Asas keterbukaan asas yang menentukan bahwa dalam segala hal ikhwal yang berhubungan dengan warga negara harus dilakukan secara terbuka;

h. Asas publisitas adalah asas yang menentukan bahwa seseorang yang memperoleh atau kehilangan Kewarganegaraan Republik Indonesia diumumkan dalam Berita Negara Republik Indonesia agar masyarakatmengetahuinya. Mengenai hilangnya

kewarganegaraan anak, maka hilangnya kewarganegaraan ayah atau ibu (apabila anak tersebut tidak punya hubungan hukum dengan ayahnya) tidak secara otomatis menyebabkan kewarganegaraan anak menjadi hilang.

2. Kewarganegaraan Ganda Pada Anak Hasil Perkawinan Campuran

Berdasarkan Undang-undang ini anak yang lahir dari perkawinan seorang wanita WNI dengan pria WNA, maupun anak yang lahir dari perkawinan seorang wanita, WNA dengan pria WNI, sama-sama diakui sebagai warga negara Indonesia. Anak tersebut akan berkewarganegaraan ganda, dan setelah anak 
berusia 18 tahun atau sudah kawin maka ia harus menentukan pilihannya. Pernyataan untuk memilih tersebut harus disampaikan paling lambat 3 (tiga) tahun setelah anak berusia 18 tahun atau setelah kawin.

Pemberian kewarganegaraan ganda ini merupakan terobosan baru yang positif bagi anak-anak hasil dari perkawinan campuran. Namun perlu ditelaah, apakah pemberian kewaranegaraan ini akan menimbulkan permasalahan baru di kemudian hari atau tidak. Memiliki kewarganegaraan ganda berarti tunduk pada dua yurisdiksi.

Indonesia memiliki sistem hukum perdata internasional peninggalan Hindia Belanda. Dalam hal status personal Indonesia menganut asas konkordasi, yang antaranya tercantum dalam Pasal 16 A.B. (mengikut) pasal 6 AB Belanda, yang disalin lagi dari pasal 3 Code Civil Perancis. Berdasarkan pasal $16 \mathrm{AB}$ tersebut dianut prinsip nasionalitas untuk status personal. Hal ini berarti warga negara Indonesia yang berada di luar negeri, sepanjang mengenai hal-hal yang terkait dengan status personalnya, tetap berada di bawah lingkungan kekuasaan hukum nasional Indonesia, sebaliknya, menurut jurisprudensi, maka orang-orang asing yang berada dalam wilayah Republik Indonesia dipergunakan juga hukum nasional mereka sepanjang hal tersebut masuk dalam bidang status personal mereka. Dalam jurisprudensi Indonesia yang termasuk status personal antara lain perceraian, pembatalan perkawinan, perwalian anak-anak, wewenang hukum, dan kewenangan melakukan perbuatan hukum, soal nama, soal status anak-anak yang dibawah umur.

Bila dikaji dari segi hukum perdata internasional, kewarganegaraan ganda juga memiliki potensi masalah, misalnya dalam hal penentuan status personal yang didasarkan pada asas nasionalitas, maka seorang anak berarti akan tunduk pada ketentuan negara nasionalnya. Bila ketentuan antara hukum negara yang satu dengan yang lain tidak bertentangan maka tidak ada masalah, namun bagaimana bila ada pertentangan antara hukum negara yang satu dengan yang lain, lalu pengaturan status personal anak itu akan mengikuti kaidah negara yang mana. Lalu bagaimana bila ketentuan yang satu melanggar asas ketertiban umum (ketertiban umum dapat diartikan sebagai sendi-sendi asas hukum nasional sang hakim). Pada ketentuan negara yang lain. Sebagai contoh adalah dalam hal perkawinan, menurut hukum Indonesia, terdapat syarat yang perlu dipenuhi yaitu:

1. Syarat materiil adalah syarat yang menyangkut pribadi calon mempelai dan larangan-larangan menikah;

2. Syarat formiil adalah syarat yang menyangkut formalitas yang harus dipenuhi sebelum perkawinan dilangsungkan. Syarat formiil biasanya terkait dengan urusan administrasi perkawinan.

Ketika seorang anak yang belum berusia 18 tahun hendak menikah, maka harus memenuhi kedua syarat tersebut. Syarat materiil harus mengikuti hukum Indonesia sedangkan syarat formiil mengikuti hukum tempat perkawinan dilangsungkan. Misalkan anak tersebut hendak menikahi pamannya sendiri (hubungan darah garis lurus ke atas), berdasarkan syarat materiil hukum Indonesia hal tersebut dilarang (pasal 8 Undang-undang Nomor I Tahun 1974), namun berdasarkan hukum dari negara pemberi kewarganegaraan yang lain, hal tersebut diizinkan, lalu ketentuan mana yang harus diikutinya.

\section{B. Batasan Hak dan Kewajiban Anak Hasil Perkawinan Campuran Menurut Undang-undang Nomor 12 tahun 2006 Tentang Kewarganegaraan Indonesia}

\section{Pada waktu Republik Indonesia} diproklamasikan pada 17 Agustus 1945, Negara Republik Indonesia belum mempunyai Undang-Undang Dasar. Sehari kemudian pada tanggal 18 Agustus 1945 Panitia Persiapan Kemerdekaan Indonesia mengesahkan Undang-Undang Dasar 1945. Mengenai soal kewarganegaraan UndangUndang Dasar 1945 dalam pasal 26 ayat (1) menentukan bahwa "yang menjadi warga 
negara adalah orang-orang bangsa Indonesia asli dan orang-orang bangsa lain yang disahkan dengan Undang-Undang sebagai warga negara", sedangkan ayat (2) menyebutkan bahwa "syarat-syarat yang mengenai kewarganegaraan ditetapkan oleh Undang-Undang". Perumusan yang demikian didasarkan pada pertimbangan bahwa bangsa Indonesia asli yang menjadi warga negara Indonesia, namun bagi mereka keturunan asing dapat pula menjadi warga negara yang diatur dalam Undang-Undang. Sebab tidak lazim masalah kewarganegaraan diatur dalam Undang-Undang Dasar dan pada waktu penyusunan Undang-Undang Dasar telah dijelaskan bahwa hal tersebut diatur dalam Undang-Undang biasa. Karena itu bagi mereka yang menjadi warga negara Indonesiaselama mereka mengakui Indonesia sebagai tanah airnya dan bersikap setia pada Negara Republik Indonesia demikian penjelasan pasal 26 tersebut.

Segala hukum pokok yang mengatur kepentingan-kepentingan perseorangan, yaitu.

1. Hukum perdata dan hukum dagang, begitu pula hukum pidana beserta hukum acara perdata dan pidana, harus diletakkan dalam kitab-kitab undangundang yang dikodifikasi;

2. Untuk golongan bangsa Eropa yang dianut (dicontoh) perundangundangan yang berlaku di negeri Belanda (asas konkordasi)

3. Untuk golongan bangsa Indonesia asli dan timur asing (Tionghoa, Arab dan sebagainya) jika ternyata "kebutuhan untuk kemasyarakatan" mereka menghendakinya, dapatlah peraturanperaturan untuk bangsa eropa dinyatakan berlaku bagi mereka, baik seutuhnya maupun dengan perubahanperubahan dan juga diperbolehkan membuat suatu peraturan baru bersama, untuk selainnya harus diindahkan aturan-aturan yang berlaku di kalangan mereka, dan boleh diadakan pernyimpangan jika diminta oleh kepentingan umum atau kebutuhan kemasyarakatan mereka;
4. Orang Indonesia asli dan orang timur asing sepanjang mereka belum ditundukkan dibawah suatu peraturan bersama dengan bangsa eropa diperbolehkan "menundukkan diri" (onderwerpen) pada hukum yang berlaku untuk bangsa Eropa. Penundukan ini boleh dilakukan baik secara umum maupun secara khusus hanya mengenai suatu perbuatan tertentu saja;

5. Sebelum hukum untuk bangsa Indonesia ditulis di dalam UndangUndang, bagi mereka itu akan tetap berlaku hukum yang sekarang berlaku bagi mereka yaitu; hukum adat.

Sebagai pelaksanaan dari pasal 26 tersebut, maka pada tanggal 10 April 1946 diundangkan Undang-Undang Nomor 3 Tahun 1946. Undang-Undang ini kemudian beberapa kali mengalami perubahan dengan Undang-tJndang Nomor 6 dan Nomor 8 Tahun 1947. Kalau diperhatikan UndangUndang tersebut akan menyatakan bahwa asas kewarganegaraan yang dianut adalah asas ius soli. Ini dapat dilihat dari rumusan dari pasal 1 huruf a, warga negara Indonesia ialah orang yang asli dalam daerah Negara Indonesia. Istilah "dalam daerah Negara Indonesia" menunjukkan pemakaian asas ius soli. Begitu pula dengan huruf $\mathrm{b}$ menyatakan, bahwa orang peranakan yang lahir dan bertempat tinggal di Indonesia paling sedikit untuk lima tahun terakhir dan berturut-turut serta berumur 21 tahun adalah warga negara Indonesia, kecuali kalau ia menyatakan keberatan menjadi warga negara Indonesia. Perkataan "lahir dan bertempat tinggal di Indonesia" ini menunjukkan bahwa asas ius soli yang dipakai. Latar belakang dari pemakaian asas ius soli ini disebabkan kenyataan bahwa sejak dahulu sudah banyak peranakan bangsa lain yang telah bertempat tinggal di Indonesia. Jadi selama mereka menyatakan kesetiannya kepada Indonesia dan mengakui Indonesia sebagai tanah airnya, maka mereka dapat menjadi warga negara Indonesia. 
Pernyataan yang dimaksud di atas harus sudah disampaikan kepada Menteri Kehakiman paling lambat dalam waktu satu tahun sejak berlakunya Undang-Undang Nomor 3 Tahun 1946 tersebut. Karena terlalu sedikit orang yang mengajukan pernyataan tersebut, maka oleh Undang-Undang Nomor 8 Tahun 1947 diberikan perpanjangan waktu sampai tanggal 10 April 1948. Hal ini sebenarnya dapat dimengerti karena Republik Indonesia pada waktu itu masih dalam peperangan dengan Belanda yang ingin kembali menjajah Indonesia. Keadaan ini berjalan terus sampai terbentuknya Republik Indonesia Serikat.

Setelah terbentuknya Republik Indonesia Serikat, maka pembuat UndangUndang Dasar 1945 juga menyadari bahwa adalah tidak mungkin untuk mengatur masalah kewarganegaraan dalam UndangUndang Dasar. Karena itu pasal 5 dari Undang-Undang Dasar 1949 menentukan bahwa kewarganegaraan 1949 menentukan bahwa kewarganegaraan Republik Indonesia Serikat diatur dengan Undang-Undang. Menyadari pula, bahwa adalah tidak mungkin membuat Undang-Undang dalam waktu yang singkat, maka pasal 194 Undang-Undang Dasar 1949 menentukan bahwa sambil menunggu Undang-Undang sebagaimana yang dimaksud dalam pasal 5 tersebut, maka yang sudah menjadi Warga Negara Republik Indonesia Serikat adalah orang-orang yang menurut persetujuan perihal pembagian Warga Negara antara Republik Indonesia dan Kerajaan Belanda, mempunyai kewarganegaraan Indonesia.

Persetujuan perihal pembagian warga negara tersebut adalah sebagian dari hasil Konferensi Meja Bundar antara Kerajaan Belanda dan Republik Indonesia Serikat.

Ada tiga hal yang penting dalam persetujuan tersebut antara lain :

1. Orang Belanda yang tetap memegang teguh kewarganegaraan Belanda. Tetapi terhadap keturunannya yang lahir atau bertempat tinggal di Indonesia sekurang-kurangnya enam bulan sebelum tanggal 27 Desember
1949, dalam waktu dua tahun setelah penyerahan kedaulatan dapat menyatakan memilih kewarganegaraan Indonesia. Di sini keturunan Belanda itu diberi kesempatan untuk memilih kewarganegaraan Indonesia, dan ini dinamakan hak opsi (hak untuk memilih kewarganegaraan) dan pemilihan kewarganegaraan di sini disebut tindakan aktif, sebagai lawan dari tindakan pasif dalam hak repudiasi;

2. Orang-orang yang tergolong sebagai kawulanegara Belanda dari golongan Indonesia asli, yang berada di Indonesia memperoleh kewarganegaraan Indonesia, kecuali mereka yang bertempat tinggal di Suriname atau di Belanda dan dilahirkan di wilayah Kerajaan Belanda, yang kemudian juga dapat memilih kewarganegaraan Indonesia;

3. Orang-orang yang menganut sistem hukum Hindia Belanda dulu termasuk golongan Timur Asing. Kawulanegara Belanda keturunan asing yang bukan berstatus orang Belanda, yaitu dikenal dengan golongan Arab dan Cina, maka terhadap mereka terdapat dua kemungkinan yaitu jika bertempat tinggal di Belanda, mereka tetap berkewarganegaraan Belanda. Mereka yang dinyatakan sebagai warga negara Indonesia, dapat menyatakan penolakannya dalam waktu dua tahun.

Dari uraian di atas, untuk menentukan siapa yang menjadi warga negara Indonesia, Persetujuan Prihal Pembagian Warga Negara tersebut menganut asas ius soli, karena baik bagi orang Indonesia asli, Arab. Cina dan keturunan Belanda yang menjadi warga negara Indonesia ditentukan pertama hahwa mereka tersebut lahir atau bertempat tinggal untuk waktu tertentu di Indonesia.

Apabila diperhatikan Undang-Undang Nomor 3 Tahun 1946 dan perihal pembagian warga negara akan nyata, bahwa terdapat ketidak tegasan dan peranakan Belanda, Arab 
dan Cina berdasarkan Undang-Undang Nomor 3 Tahun 1946 telah menjadi warga negara Indonesia dengan tidak mengajukan penolakan seperti diharuskan, mereka belum dianggap sebagai warga negara Indonesia sampai mereka mengadakan pilihan.

Pasal 5 ayat (1) Undang Undang Dasar menentukan bahwa Kewarganegaraan Republik Indonesia diatur dengan UndangUndang dan sementara badan legislatif menyusun Undang-Undang dimaksud, maka oleh ketentuan peralihan pasal 144 ditentukan bahwa yang dimaksud atau yang menjadi warga negara Republik Indonesia ialah mereka yang berdasarkan Undang-Undang Nomor 3 Tahun 1946 dan Persetujuan prihal pembagian warga negara, sudah menjadi warga negara Indonesia.Walaupun pembagian warga negara telah diberikan kesempatan kepada khususnya golongan cina untuk memilih warga negara Indonesia, tidaklah berarti bahwa mereka telah sepenuhnya warga negara Indonesia, karena Undang-Undang Kewarganegaraan Republik Rakyat Cina pada waktu itu menganut asas ius sanguinis, dan seperti telah dijelaskan diatas, pembagian warga negara menurut Undang-Undang Nomor 3 Tahun 1946 menganut asasius soli. Menurut penjelasan dimuka bahwa apabila terjadi dua asas yang bertentangan ini akan menimbulkan bi-patride (dwi kewarganegaraan) dan memang pada waktu itu banyak terjadi dwi kewarganegaraan atas golongan Cina.

Seperti telah dijelaskan di muka, bahwa satu-satunya usaha untuk memperoleh pemecahan adalah mengadakan perjanjian antara negara yang bersangkutan dan untuk itu telah ditandatangani perjanjian SonarioChou pada tanggal 22 April 1955. Dalam perjanjian itu ditentukan bahwa kepada semua orang Cina ditentukan untuk melakukan pilihan dengan tegas dan secara tertulis apakah tetap akan menjadi warga negara Republik Indonesia. Kesempatan untuk memilih itu dalam waktu dua tahun setelah perjanjian itu berlaku. Perjanjian ini kemudian menjadi Undang-Undang Nomor 2 Tahun 1958. Oleh Pemerintah Orde Baru perjanjian ini kemudian dicabut dengan Undang-Undang Nomor 4 Tahun 1969 tanggal 10 April 1969. Karena UndangUndang ini sudah tidak sesuai lagi dengan perkembangan ketatanegaraan Republik Indonesia, maka dicabut dan seluruh produk lama tidak berlaku lagi karena diganti dengan Undang-Undang Nomor 12 Tahun 2006 tentang Kewarganegaraan Republik Indonesia yang disahkan DPR pada tanggal 11 juli 2006.

Undang-Undang No. 12 Tahun 2006 Tentang Kewarganegaraan Republik Indonesia yang disahkan Presiden pada tanggal 1 Agustus 2006 ini, sebagai pelaksana dari pasal 5 ayat (1) Undang-Undang Dasar 1950, legislatif mampu untuk menyusun suatu Undang-undang

KewarganegaraanRepublik Indonesia.

Berlainan dengan Undang-Undang Nomor 62 Tahun 1958 yang menitik beratkan pada asas ius sunguinis, walaupun dalam halhal tertentu masih memakai asas ius soli. Undang-Undang tersebut menyebutkan bahwa keturunan dipakai sebagai suatu dasar adalah lazim. Sudah sewajarnya suatu negara menganggap seorang anak sebagai warga negara dari negara itu. Hal itu dapat dilihat dari ketentuan pasal 1 huruf; b, c dan e, yang kesemuanya menentukan hahwa seseorang anak adalah warga negara Indonesia karena kedua orang tuanya atau salah seorang dari orang tuanya berkewarganegaraan Indonesia.

Maka Undang-Undang Nomor 12 Tahun 2006 menegaskan anak yang lahir dari ibu orang Indonesia dan ayah orang asing tidak otomatis mengikuti warga negara ayahnya. Bahkan, pada saat bersamaan, anak boleh menjadi warganegara Indonesia dan warganegara ayahnya hingga usia 18 tahun. Setelah itu, sang anak boleh menentukan kewarganegaraan yang dipilih.

Asas ius soli dipakai sebagai dasar untuk menentukan kewarganegaraan oleh Undang-Undang tersebut adalah sebagai pengecualian, karena asas ini hanya khusus untuk mereka atau anak-anak yang lahir di wilayah Indonesia yang baik kedua orang tuanya tidak diketahui, atau orang tuanya 
Evi Purnama Wati, Analisa Yuridis Tentang Status Kewarganegaraan Anak Hasil Perkawinan Campuran Menurut Undang-Undang Nomor 12 Tahun 2006 Tentang Kewarganegaraan Indonesia, halaman 42-56

tidak mempunyai kewarganegaraan atau mungkin belum mendapat kewarganegaraan dari negara orang tuanya, hal ini diatur dalam pasal 4 Undang-Undang Nomor 12 Tahun 2006 tentang Kewarganegaraan Republik Indonesia.

Maka jelas bahwa Undang-Undang ini tidak mengenal kewarganegraan ganda (bipatride) ataupun (a-patride), Kewarganegaraan ganda yang diberikan kepada anak dalam Undang-Undang ini merupakan suatu pengecualian. Seorang anak yang lahir dari perkawinan seorang ibu WNI dengan Pria WNA, yang kemudian bercerai, atau dilahirkan diluar perkawinan dimana ibunya Warga negara Indonesia, mengikuti kewarganegaran ayahnya ataupun ibunya, setelah berusia delapan belas tahun untuk menentukan pilihan. Dalam perspektif ini, kita menganut prinsip kewarganegaraan terbatas.

Demikian pula Undang-Undang tersebut juga berusaha untuk mencegah timbulnya bi-patride. Hal ini dapat ditunjukkan dengan beberapa ketentuan dalam Undang-Undang tersebut. Dalam hal antara anak dan bapaknya tidak ada hubungan, maka si anak mengikuti kewarganegaraan ibunya. Agar jangan sampai terjadi tanpa kewarganegaraan bagi anak-anak yang lahir di Indonesia sedang orang tuanya tidak diketahui atau orang tuanya tidak mempunyai kewarganegaraan, maka oleh UndangUndang tersebut dinyatakan bahwa mereka adalah warga negara Indonesia, dan salah satu kegunaan dipakai asas ius soli adalah untuk mencegah a-patride .

Begitu pula bagi perempuan warga negara Indonesia yang kawin dengan laki-laki warga negara asing, baru dapat meninggalkan Indonesia, apabila jelas bahwa negara asal suaminya memungkinkan bagi dia untuk mendapatkan kewarganegaraan. Kalau tidak demikian, maka kemungkinan perempuan Indonesia tadi akan menjadi a-patride, sebab dia telah terlanjur meninggalkan kewarganegaran Indonesia. Sementara itu negara asal suaminya tidak memungkinkan bagi dia memperoleh kewarganegaraan.
Naturalisasi

(pewarganegaraan) adalah suatu cara untuk memperoleh kewarganegaraan Indonesia oleh orang asing. Sudah sewajarnya dibuka kemungkinan bagi orang asing yang sungguh-sungguh ingin menjadi warga negara Indonesia, namun tentu saja kepentingan negara dan bangsa Indonesia juga harus diperhatikan, dan karenanya dalam setiap Undang-Undang dapat dilihat bahwa pewarganegaraan ini adalah kebijaksanaan eksekutif. demikian pendapat UndangUndang Nomor 12 Tahun 2006.

Naturalisasi dalam praktek dapat dibagi dua, yaitu pertama karena yang bersangkutan mengajukan permohonan dan yang kedua dapat diberikan dengan kepentingan negara atau telah berjasa untuk negara. Pada naturalisasi syarat pertama, bahwa menurut Undang-Undang Nomor 3 Tahun 1946 naturalisasi itu diperoleh dengan berlakunya Undang-Undang yang memberikan naturalisasi itu. Naturalisasi harus dibicarakan terlebih dahulu dengan Dewan Perwakilan Rakyat. Apabila Dewan Perwakilan Rakyat tidak keberatan dengan permohonan itu, maka harus dinyatakan dalam Undang-Undang. Sebaliknya UndangUndang Nomor 12 Tahun 2006 menyatakan bahwa naturalisasi itu semata-mata tindakan dari eksekutif. Dan karena kebijaksanaan pemerintah, maka tidak perlu diminta persetujuan dari Dewan Perwakilan Rakyat, namun Menteri Hukum dan HAM tidak dapat memutuskan tanpa mendapat persetujuan terlebih dahulu dari Dewan Menteri. Sedangkan naturalisasi syarat yang kedua, baik Undang-Undang produk lama maupun Undang-Undang Nomor 12 Tahun 2006, sama-sama mengatur bahwa pewarganegaraan yang diberikan dengan alasan kepentingan atau berjasa untuk negara harus diminta persetujuan Dewan Perwakilan Rakyat terlebih dahulu, dan persetujuan Dewan Perwakilan Rakyat pada akhirnya harus dalam bentuk Undang-Undang. Bahwa hal itu harus demikian dapat dimengerti, karena seharusnyalah wakil-wakil yang mengetahui sejauh manakah kepentingan negara tersangkut, sehingga orang asing dapat 
Evi Purnama Wati, Analisa Yuridis Tentang Status Kewarganegaraan Anak Hasil Perkawinan Campuran Menurut Undang-Undang Nomor 12 Tahun 2006 Tentang Kewarganegaraan Indonesia, halaman 42-56

diberikan kewarganegaraan Indonesia, atau sejauh manakah jasa dari orang yang bersangkutan untuk negara Indonesia.

Bagaimana dengan anak-anak orang yang berstatus warga negara Republik Indonesia dengan ayah yang berstatus warga negara Republik Indonesia dan sang anak harus ada hubungan suatu kekeluargaan yang sah menurut hukum. Jika tidak ada hubungan hukum antara anak dan ayah ini, status sang anak mengikuti status sang ibu. Tegasnya status sang anak digantungkan kepada status ayahnya (cg. Ibunya) yang sah. Dengan demikian dipentingkan faktor keturunan. Faktor tempat kelahiran tidak demikian dipentingkan. Juga bilamana anak yang bersangkutan dilahirkan diluar Republik Indonesia ia ini dianggap sebagai warga negara Republik Indonesia jika ayahnya adalah warga negara Republik Indonesia.

Anak-anak yang dilahirkan dari seorang ayah yang tidak mempunyai kewarganegaraan atau yang kewarganegaraannya tidak diketahui, mengikuti status dari ibunya, yang berkewarganegaraan Republik Indonesia. Disini kita saksikan bahwa pembuat UndangUndang melindungi sedapat mungkin akan sang anak. Jika sang ayah dari anak bersangkutan tidak mempunyai kewarganegaraan (a-patride) atau tidak diketahui status kewarganegaraannya, maka anak bersangkutan juga akan menjadi tanpa kewarganegaraan, jika terus mengikuti status ayahnya dan dalam UndangUndang kewarganegaraan justru sedapat mungkin hendak dihindari terjadinya keadaan tanpa kewarganegaraan ini. Harus dihindarkan bahwa seorang anak ini akan menjadi tanpa kewarganegaraan. Maka tentukanlah hahwa antara sang ibu dan anak dalam bidang kewarganegaraan ini akan selalu terdapat hubungan kekeluargaan. Karena sang ibu bersangkutan berstatus warga negara Indonesia, maka dipandang sebaiknya jika sang anak diberikan pula status warga negara Republik Indonesia ini dari pada menjadi tanpa kewarganegaraan.
Bagaimana terhadap hak dan kewajiban anak-anak hasil perkawinan campuran (berkewarganegaraan ganda) Secara sosiologis, Undang-undang ini sudah sangat sesuai dengan perkembangan dan tuntutan masyarakat Indonesia dalam tata pergaulan global; mereka dapat berhubungan dengan warga negara lain, tentunya menghendaki adanya persamaan perlakuan dan kedudukan sebagai warga negara di hadapan hukum serta adanya jaminan kesetaraan dan keadilan gender.

Walaupun banyak menuai pujian, lahirnya Unadng-undang ini, juga masih menuai kritik dari berbagai pihak. Salah satu pujian sekaligus kritik yang terkait dengan status kewarganegaraan anak perkawinan campuran datang dari KPC Melati (organisasi para istri warga negara asing). Secara sosiologis adanya kewarganegaraan ganda terbatas dalam undang-undang kewarganegaraan Republik Indonesia yang baru, telah merespon kehendak sosial masyarakat. Khususnya dalam konteks ke kinian pada masyarakat majemuk dan global, terutama sebagai imbas dari adanya perkawinan campuran (antar warganegara).

Selama hampir setengah abad pengaturan kewarganegaraan dalam perkawinan campuran antara Warga Negara Indonesia dengan warga negara asing, mengacu pada Undang-Undang Kewarganegaraan Nomor 62 Tahun 1958. Seiring berjalannya waktu Undang-undang ini dinilai tidak sanggup lagi mengakomodir kepentingan para pihak dalam perkawinan campuran, terutama perlindungan untuk istri dan anak. ${ }^{3}$

Adanya kewarganegaraan ganda tersebut, maka anak akan tunduk pada dua yurisdiksi hukum. Bila dikaitkan dengan hakhaknya di bidang politik tentu tetap memiliki hak berekspresi, hak berserikat, hak dalam

\footnotetext{
"Status Hukum Anak Hasil Perkawinan Campuran Berdasarkan Hukum Indonesia" dalam http://jurnalhukum.blogspot.com/2012/12/st atus-hukum-anak-hasil-perkawinan.
} 
persamaan perilaku di depan hukum serta hak memilih dan dipilih. Sebuah hal yang mungkin tidak pernah terlintas dalam kontek sosial kemasyarakatan sebelumnya. Namun lagi-lagi secara sosiologis itulah kenyataan empiris dan telah dituangkan secara yuridis yang terjadi dalam undang-undang kewarganegaraan Republik Indonesia saat ini.Seseorang warga negara berstatus kewarganegaraan ganda terbatas secara hukum diakui keberadaannya sebagai warga negara di kedua negara yaitu Warga Negara Indonesia dan Warga Negara Asing. Oleh karena ia adalah warga di kedua negara, maka hak-hak yang melekat karena status kewarganegaraannya harus juga diberikan utuh oleh negara dan negara tidak boleh membatasi hak-haknya sebagai warga negara. Hak-hak yang dimaksud adalah termasuk hak pilih dalam pemilu, hak memperoleh pendidikan, hak mendapatkan jaminan sosial dan lain-lain. Beranjak dari beberapa ketentuan di atas, bagi anak yang memiliki kewarganegaraan ganda terbatas yang telah berusia 17 tahun ke atas, maka secara otomatis berhak untuk memilih. Karena tidak ada aturan hukum yang melarang dalam menggunakan hak pilihnya. Tentunya tetap mengikuti prosedur untuk menjadi pemilih. Hal ini ditunjang oleh argumen bahwa hak pilih (yaitu hak memilih dan hak dipilih) merupakan bagian tidak terpisahkan dari hak asasi manusia yang diakui dalam berbagai ketentuan tersebut diatas.

\section{PENUTUP}

\section{E. Kesimpulan}

1. Status kewarganegaraan anak yang lahir dari perkawinan campuran menurut Undang Undang Nomor 12 tahun 2006 Tentang Kewarganegaraan Indonesia adalah; memberikan pencerahan yang positif, karena Undang-Undang ini mengizinkan kewarganegraaan ganda terbatas untuk anak hasil perkawinan campuran, sampai batas umur 18 tahun, maka anak berhak memilih kewarganegaraan yang diinginkannya dan diberikan waktu untuk berpikir selama 3 tahun. Sedangkan di dalam Undang-Undang Nomor 62 tahun 1958 tentang Kewarganegaraan, Status kewarganegaraan anak mengikuti kewarganegaraan ayahnya.

2. Batasan hak dan kewajiban anak yang lahir dari perkawinan campuran menurut Undang-undang Nomor 12 Tahun 2006 tentang kewarganegaraan Indonesia adalah;Mempunyai hak dan kewajiban yang sama yaitu; Seseorang warga negara berstatus kewarganegaraan ganda terbatas secara hukum diakui keberadaannya sebagai warga negara di kedua negara yaitu Warga Negara Indonesia dan Warga Negara Asing. Oleh karena ia adalah warga di kedua negara, maka hak-hak yang melekat karena status kewarganegaraannya harus juga diberikan secara utuh oleh negara dan negara tidak boleh membatasi hakhaknya sebagai warga negara dari kedua negara.

\section{DAFTAR PUSTAKA BUKU-BUKU;}

Abu Huraerah, Kekerasan Terhadap Anak, Nuansa Jakarta, Cet, ke II, 2006.

CTS, Kansil, Hukum Kewarganegaraan Indonesia, Sinar grafika, Cetakan I, Jakarta.1992.

Frans H. Winarta, Jalan Panjang Menjadi WNI, Buku Kompas, Jakarta, 2007.

Hadi Setia Tunggal, Tanya Jawab Kewarganegaraan Baru Berdasarkan Undang - Undang Nomor 12 Tahun 2006, Harvarindo, Jakarta, 2006.

Mohd. Idris Ramulyo, Hukum Perkawinan Islam, Sinar Grafika, Jakarta, 2004

Sjahran Basah, Hukum Tata Negara Perbandingan, Alumni, Bandung, 1981. 
Evi Purnama Wati, Analisa Yuridis Tentang Status Kewarganegaraan Anak Hasil Perkawinan Campuran Menurut Undang-Undang Nomor 12 Tahun 2006 Tentang Kewarganegaraan Indonesia, halaman 42-56

Soehino, Hukum Tata Negara Sumber sumber Hukum Tata Negara Indonesia, Liberty, Yogyakarta, 1985.

Sri Susilowati Mahdi, Sunni Ahlan Sjarif, dan Akhmad Budi Cahyono, Hukum Perdata Suatu Pengantar, Gitama Jaya Jakarta, Jakarta, 2005.

S. Gautama, Hukum Perdata Internasional Indonesia, Alumni, Bandung, 1995.
Wibowo Reksopradoto, Hukum Perkawinan Nasional, Seksi Hukum Perdata, Fakultas Hukum Universitas Diponorogo, 1982.

\section{Perundang-undangan;}

Undang-Undang Dasar Republik Indonesia 1945

Undang-undang Nomor 52 Tahun 1958 tentang Kewarganegaraan Indonesia lama Undang-undang Nomor 12 Tahun 2006 tentang Kewarganegaraan Indonesia Baru 